\author{
$11^{\text {th }}$ International Conference on \\ Malaysia-Indonesia Relations (PAHMI 11) \\ Universitas Indonesia, 14-16 August 2017
}

\title{
MALAYSIA - INDONESIA: IN THE VORTEX OF INTERPRETATION
}

\author{
Bambang B. Sulistiyono dan Mohd Zaidi Hajazi \\ Dosen Manajemen Unsurya, Jakarta dan Professor of Sociology and \\ Director, Institute of Malaysia Indonesia Studies (IKMI) Universiti Selangor, Malaysia \\ bangsul76@gmail.co.id dan zaidihajazi@yahoo.com
}

\begin{abstract}
Malaysia and Indonesia are two countries with a relationship that is very unique. Its society has established kinship long before the two countries was formed, which resulted similarities in each other's culture and customs. Both countries also play a very important role in associations of the Southeast Asian nations that is accommodated through the ASEAN forum. However, the relationship between Malaysia and Indonesia have not always been great, sometimes it touches the lowest state and at other times at the most harmonious. The Realist and Liberalist theory applies in studying relations between these two countries. Although waves of problems coming and going may occur naturally, plenty of formal efforts has also been done by both governments. There are three interesting time periods in this study; the relationship period most bitter (1963-1966), the most harmonious relationship period (1968-1982), and the period of friendly but tense relations (19832010). Assessment of the two countries' relationship dynamics is done through in qualitative approach with comparative analaysis and supported by the "Taxonomy Bloom" method. Many main informans with different backgrounds are the core informants who supported this study. Some are former government officials, academicians, military personnel and citizens who have had a history of being directly involved in the confrontation and many of the accuracy of data information can produce. From a comprehensive study a case was found, identifying that interpretation differences as well as similarities is what causes the two countries' relationship experience highs and lows. Also through this study, the root of the problem can be understood therefore suggestion of solutions can be submitted.
\end{abstract}

Key words : Interpretation, Conflict And Cooperation

\section{PROBLEM BACKGROUND}

Malaysia and Indonesia possess many similarities, especially in culture, language, religion and mores aspects. However, the bilateral relationship between Malaysia and Indonesia until now can be said to always experience ups and downs, although various attempts have been made to muffle the emergence of larger issues.

The dynamics of conflict arose from the emergence of different interpretations evolving into mutual mistrust of one another, when the world in general and Southeast Asia in particular were influenced by the conflict between the Communist and Capitalist Blocks.

Mistrust is very reasonable because there are differences in the historical background of the two countries. Indonesia gained independence through "resistance" to Western colonialism, while the formation Malaysia Raya was loaded with interest to 
maintain Capitalism.

Two important events emerged almost simultaneously, namely the completion of the West Irian dispute on Octover 1, 1962 and the arising of rebellion in North Borneo on December 8, 1962, caused more mistrust for Malaysia. Reasoned by this, the Tanah Melayu Federation Government considered that Indonesia's "political confrontation" against Malaysia is not caused by the independence of Malaysia, however was a logical consequence of the Indonesian government's long term politics (Hadiningrat, 1971). Since then, from April 12 to September 18, 1963, there have been 20 incidents of combat infiltration of by armed infiltration in Sarawak. Malaysia considered that Indonesia launched the first provocative action against the British before its' colonial land joins the Federation of Malaysia (Omar, 1969).

For Indonesia, mistrust towards Malaysia has grown upon the idea of Malaysia's formation by Lord Brissey, Director of British North Borneo Company, which occured before Malaysians themselves proposed the idea. British's strategy background on the nation of Malaysia's formation is to maintain it's economic interest in Malaysia, as well as for the strategic importance of maintaining one of the defence line key links that runs from UK through Giblatar and Aden directly to Singapore, to ensure Malaysia remains pro of the Britishbacked towards Western (Hadiningrat, 1971). The existence of the British interest behind the idea of establishing Malaysia has further strengthened Indonesia's mistrust, that the purpose of British capitalist veil will disturb the interest of Indonesia.

If during the early days issues of the poor relationship between Indonesia and Malaysia are caused by mistrust,further in time the national interest of each countries embodied in political actions often provide different intepretations. Both countries interpretation dissimilarities is the reason for the emergence of social open conflicts, with different conflict techniques. Oftentimes these disinterpretation dissimilarities occur at the same time period, where leaders of both nation sometimes have the same interest, but for different aimings. This argumentation can be justified with a case alike - the civil war between India and Pakistan which fought for its influence over the Khasmir territory. And also the war between South and North Vietnam, as well as the civil war between South and North Korea where they defended their ideology.

As seen by the Malaysia-Indonesia relationship dinamic explained, there are three period to highlight - the relationship period most bitter (1963-1966), the most harmonious relationship period (1966-1998), and the period of friendly but tense relations (19982010).

Data of the Malaysia-Indonesia conflict frequency obtained by current research result of relevant newspaper and journal articles and also official documents of literature are 
shown in table 1 below

\section{Frequency Conflict}

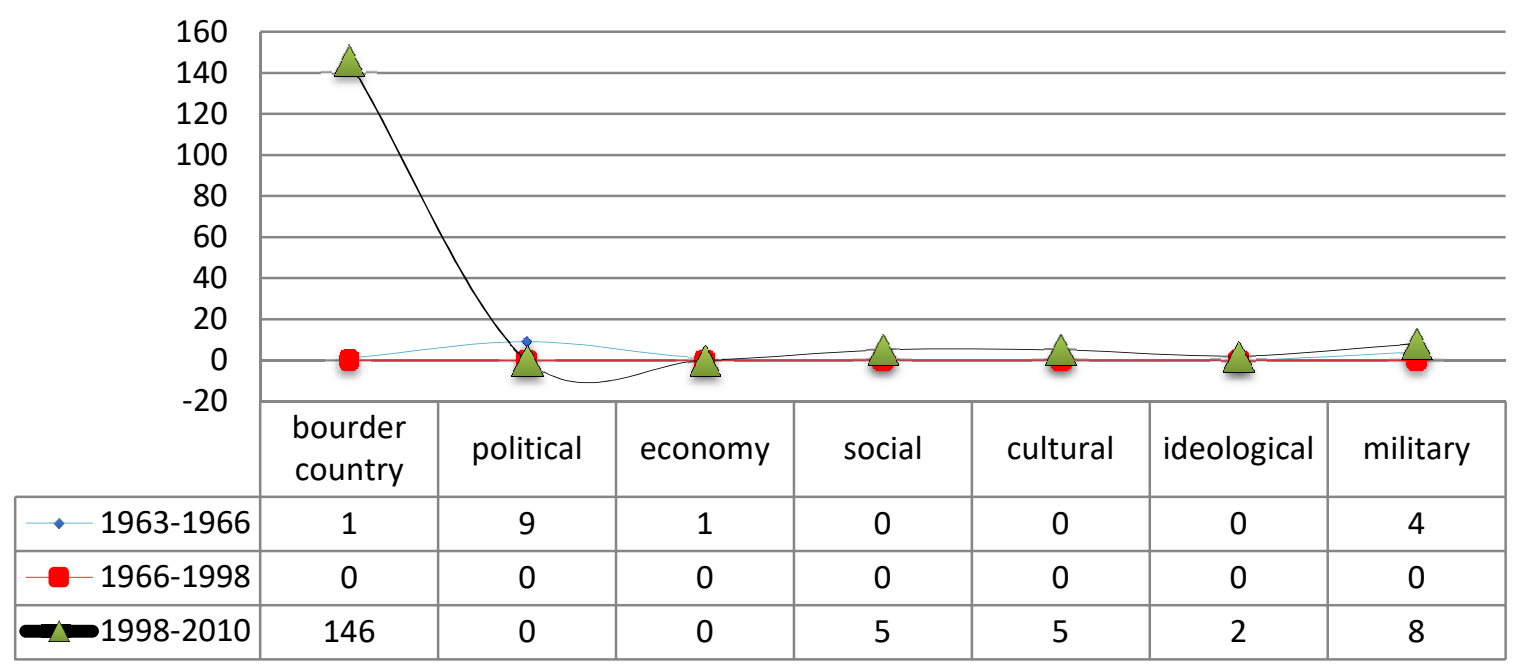

Looking at the above graphic, it can be explained that conflicts occuring during 19631966 is lower in numbers than 1998-2010. There were three causes of conflict during 1963-1966, namely economic, military and political aspects, with political conflict as the most dominant at $64 \%$, followed by the military force at $29 \%$. Whilst during 19661998 there were no conflicts, in 1998-2010 the intensity of issues increased in the ideological, social, cultural, military and territorial areas. $88 \%$ of conflicts during those years were dominated by territorial issues, followed by the use of military force reaching $5 \%$.

\section{STUDI OF ISSUE}

The interpretation differences or the way issues are interpreted will not have a negative impact when its influence is low, however the impact will be tremendous if the interpretation differences occur to those with strong influence during its timing. If the character of a national leader owns different interest then both nations relationship will deffinitely be affected. But if the state leaders have similarities in their interpretation, then relationship between both nations will be well-established (Sunarti, 2014).

A case of confrontation, for example, occured due to the contrast interpretation between Tengku Abdul Rahman and Sukarno. Whereas when Soeharto had similar interpretation with Tun Abdul Razak, both countries' relationship seems to be harmonious and also led to the formation of the association of Sountheast Asian Nations (ASEAN). However as time goes by, technological developments drive the acceleration of information flow and the world undergoes social environment changes towards globalization, the alteration from generations to generations continues and the 
evolution of their character can not be avoided. This has direct impact towards how the kinship relationship between Indonesians and Malaysians which was inherited from their ancestors, is viewed between Indonesians and Malaysians. This condition is what is seen now. Interpretaion differences occurs in a bigger scale in all life aspects namely politics, economy, social and cultural also security. This is different from when confrontational events that occurs in caused by only three aspects of interpretation difference - politic, economy and security.

\section{RESEARCH METHODOLOGY}

There are two objectives of this study; 1. The general purpose of knowing the attitudes and opinions of the informants (historian, government officials, community leaders, academics and communities) in looking at the phenomenon of MalaysiaIndonesia's tension over the years, 2. On a more spesific purpose, to explore best pratices therefore conflicts between Malaysia and Indonesia can be avoided.

To achieve these goals, a qualitative research methodology through a comparative approach is used. It is considered as the most appropriate method to answer the phenomenon of a common yet complex (holistic) matter, and the issues to be investigated are also very dynamic and meaningful, making it is not possible tobe extracted by a quantitative research method. In this study, selection of informants is done by purposive sampling which are chosen based on consideration of a specific goal, and also the snowball sampling. Data collection is a key step, therefore it is done with an indepth interview to understand the perceptions of each individuals towards the phenomenon being studied.

\section{ANALYSIS AND DISCUSSION}

In this section, the findings of the study which was discussed with nine core informants, namely former government officials, academics who did various studies on the Malaysia-Indonesia relations, also two important informants who are former military members that were directly involved in confrontation, as well as one military historian. The former government officials informant was elected considering their understanding of the dynamics, political situation and political policy applied at that time. While the intellectuals were chosen because they are considered to have had studied or even examinded the MalaysiaIndonesia relationship comprehensively, with the theories they found. Military informants were selected to complement the data from the core sources, as their involvement in war is considered to have strong correlation with policies made by the state leader at that time. Likewise, military historians were chosen as informants because they have done various studies of the military background in times of confrontations.

This study has three main domains of the study which are answered based on questions, namely cognitive domain, affective 
domain and psychomotoric domain. From the three main domains the study was further developed into fifteen categories and fifteen research questions. Based on the research questions, the information and data collected are analyzed, resulting the following:

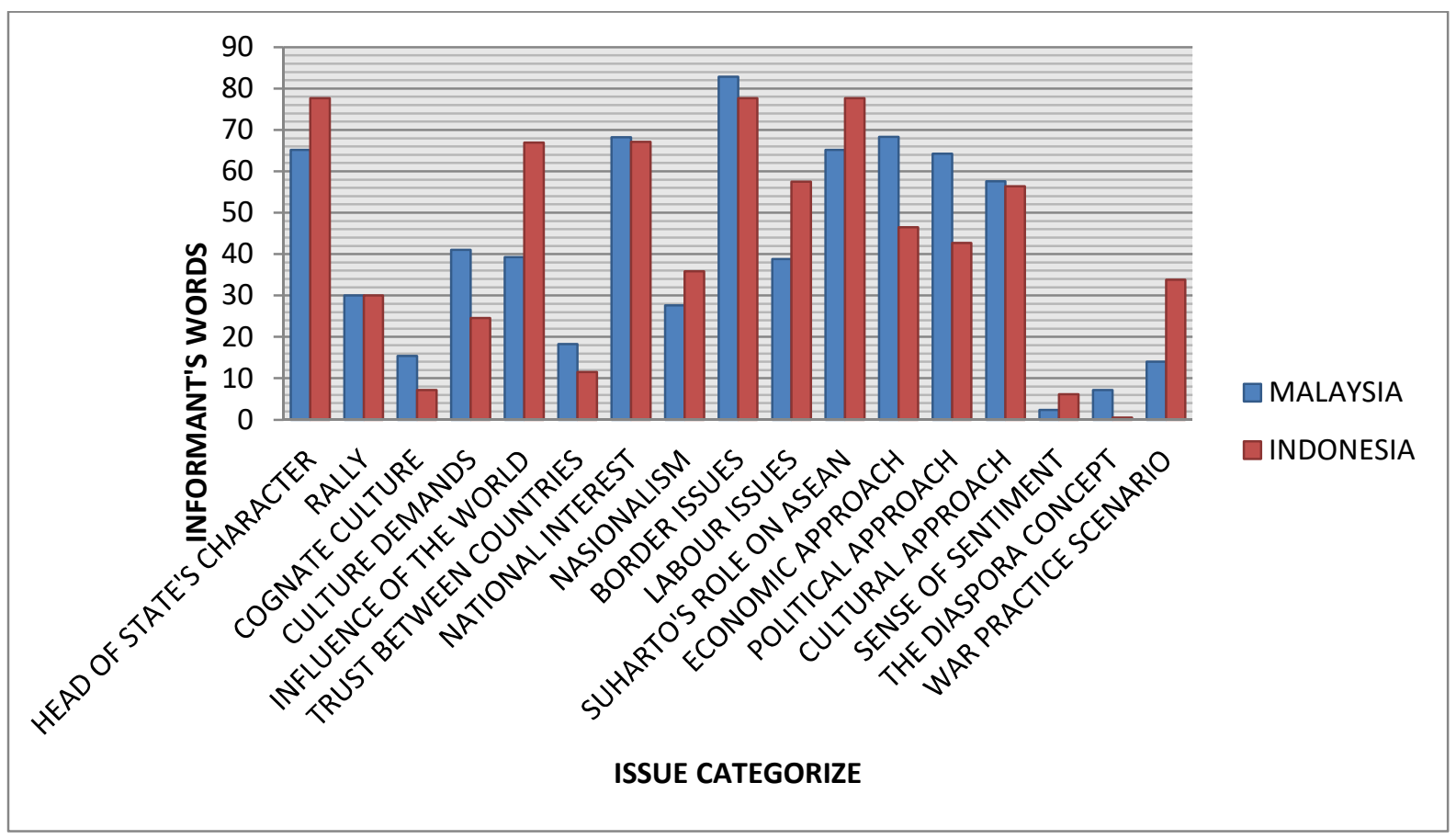

1. In the Malaysia-Indonesia relation during this time, character of the state leader strongly influenced the political policy of both countries. The opinion polls show Malaysians expresses $65,19 \%$ and Indonesians $77,71 \%$. This means that over $50 \%$ of both countries' communities recognize the role of state leaders in influencing the relationship tides between the two countries.

2. Although often politicized and influenced by media, the occurrence of hostility ripples by a group of people in both countries in the form of rallies that have been happening, is understood to not develop into a large-scale enmity. This is indicated by the average public opinion of the two countries which is not more than $30 \%$.

3. The understanding of the two nations towards assimilation processes that ever happened has a very low influence on their socio-cultural behavior. For Malaysia it reached 15,4\% and Indonesia $7,2 \%$. This means that in interactions, both nations always use the same feelings. However, this should be remained underlined, because those feelings are still under $20 \%$, meaning that the potential for having different feelings persists. Linda Sunarti (2014) states in her theory "the same language, religion, and history do not become a strong binding factor for relations between the two countries". 
4. Culture in terms of politics, economics and nationality of a nation has a high value. This means both nation tried to get culture recognition. It is proved that the desire of Malaysians to gain culture recognition is quite high, above $41,02 \%$ on average, compared to the average Indonesians at only $\mathbf{2 4 , 6 \%}$. This can be interpreted that the desire of Malaysians seeking identity is very strong, because of the competition with Chinese and Indian ethnics. Unlike Indonesians who feel that they already have a stronger culture.

5. The intriguing interest of the world between the western bloc and the eastern bloc has dragged both countries within its sphere of influence. The condition is felt deeply by the people of Indonesia, seen from the $66,95 \%$ expression reached, compared to Malaysia with only $39,25 \%$. The substantial gap shows the sensitivity of the Indonesian people towards Westernoriented Malaysian political attitudes. This is felt because until now Malaysia still cooperates with commenwealth countries , and during confrontations Malaysia is also engaged in the FPDA which was designed by UK.

6. The development of the world after the end of the cold war, led to the tendency of many countries to form colonies for their economic interests, such as ASEAN. From the opinion poll result, the percentage number obtained for Malaysia reached $18,36 \%$ and
Indonesia 11,48\%. Both figures are still under $20 \%$, indicating that confidence in ASEAN still contains vulnerability, for example the Brecit case which occurred in the EU despite it being 40 years old.

7. National interests can serve as a benchmark or criterion of a country in formulating its basic foreign policy stance. The gathering of opinion resulted that the way Malaysians and Indonesians view of each country's national interest is quite balanced, where the highest number is reached by Malaysia with $68,19 \%$ and Indonesia with $67,15 \%$. This means that both countries understand and appreciate the national interests that runs in their respective countries.

8. Nationalism means the pride and love of the homeland. Therefore, the balance of nationalism among neighboring countries needs to be preserved in the international world. If each country adheres to this view it can be assured that no conflict, caused by one country haveing more nationalism than the other, will arise. In this aspect, the sense of Indonesian nationhood is higher with an average of $35,88 \%$, compared to Malaysian of $27,58 \%$. The importance of both nations to understand mutual respect for each other is at foremost.

9. The case of the maritime border between Malaysia and Indonesia is highly susceptible, because it extends throughout the entire Malacca, and international 
interests also its boundaries rely solely on the points of imagination. The sensitivity of the border issue received the same great attention from both communities, as seen from the Malaysian opinion reaching an average of $82,87 \%$ and Indonesia reaching $\mathbf{7 7 , 7 1 \%}$. It can be interpreted that both communities have high awarness of the vulnerability in the Malacca Strait, suggesting both countries to be more serious in resolving the issue. Both countries must have the political will to resolve the border issue.

10. The Indonesian labor (TKI) is actually a symbiotic case, but when problems arise it can be troublesome for both governments. The case often occurs due to a group of Indonesians interpreting it differently, judging Malaysia not having respect towards the Indonesian citizens. On the other hand, Malaysians consider it as not the main narrative. This condition can be seen from the number of Indonesian people's expressionwhich reached $57,53 \%$, while Malaysia is only at $38,81 \%$. Of course this can not be ignored because the percentage difference is significant enough to reach $20 \%$, therefore the two countries should seriously consider the employment problem as an obstacle that must be resolved soon.

11. Building trust among nations is not easy because the interpretation or understanding towards other nations are not always the same. The establishment of ASEAN, which was initiated by five countries namely Malaysia, Indonesia, Thailand, Singapore and the Philippines, serves as a historical moment. Its survival and strength until today is proof of the belief. One of the key factor is Suharto, an important figure capable of acting as a unifier. This opinion was recognized by both communities seen with Malaysia at $65,19 \%$ and Indonesia at $77.71 \%$. Interestingly, based on that experience, both nation should be able to maintain harmony through the kinship that was once exemplified by the figure of Suharto.

12. Sentiment is a person's way of thinking based on excessive feelings that lead to negative feelings, due to the influence of stimulus or stimulation beyond one's self. This case is illustrated by the Indonesian military members, who are prisoners of war in Malaysia, being tortured from hateful people. But the hatred turns into intimacy when the confrontation comes to an end. From the opinion gathering a result was shown - that sentiment between Malaysian and Indonesian communities in the confrontation period is in fact not very strong. This can be seen as only $6,14 \%$ in Indonesian expressed so, and only $\mathbf{2 , 3 3 \%}$ Malaysians expressed the same.

13. Malaysia's psychological memory of seeing Indonesia as aggressive as the Majapahit kingdom conquering the Malacca peninsula, prevailed in its 
national security system. Seen in every scenario of warfare training, it is always presupposed that Indonesia is a threat to be faced. Hence, this raises suspicion towards Indonesia. The suspicion can be seen from the resultwhere Indonesian reached the average of $33,84 \%$, compared to Malaysian informants at $13,99 \%$.

14. Peace is an idea that is always desired by all parties who experience weary in disputing. The economic approach as a solution of peace is strongly recommended, because it contains the potential of silahturahmi between communities located near each other. Although it contains the principle of competition, it does not mean to attack or defeat each other. The opinion poll result shows that the economic approach gets bigger attention from the Malaysian society, reaching $68,31 \%$, compared to Indonesian at $\mathbf{4 6 , 5 3 \%}$. The condition is inseparable from the better stability of the Malaysian economy. However, the economic approach as a peaceful solution is still of paramount importance expected by both neighboring countries.

15. A political approach to a peaceful solution can be done if other conflict resolution can no longer be used. A political approach through diplomacy is a political approach model commonly used in an international settlement effort called positive peace. However, the opinion poll result shows a different response.
Malaysian society puts superior trust with value as high as $64,30 \%$, while Indonesia only reached $\mathbf{4 2 , 7 0 \%}$. This shows that Indonesian people lack confidence in the political will of Malaysia, possibly resulting from the feeling of being more disadvantaged. Amongst others, such as labor cases, and also the Sipadan and Ligitan islands dispute case.

16. The approach to problem resolution has been made continuously by both countries. However its formalistic approach is rigid, hence the result is not be permanent. Therefore, the cultural approach is proposed as a substitute solution, because of its supple and flexible nature. This is evidenced by the intensity of cultural interaction over the course of time being above the interactions in other fields. This approach got similar response from both countries, with Malaysians reaching $\mathbf{5 7 , 6 2 \%}$ and Indonesians at $56,43 \%$.

17. The diaspora concept has been proposed to be applied with the aim of bringing the relationship between the two nations closer, which are thought to have declined in the younger generation. From the result obtained, the fact that the value of support to the concept of diaspora in the Malaysian society is as low as $7,20 \%$, and even only $0,52 \%$ in the Indonesian society. This shows that the concept will be less effective if applied, because to not all Indonesian tribes are 
equal to the tribe in Malaysia. It is only effective if applied in a limited way to certain communities that currently posses kinship, especially in the Malacca and Sumatra peninsula.

\section{CONCLUSION}

From the analysis and discussion above, it can be seen that the MalaysiaIndonesia bilateral relationship is unique because of its very close relationship and play an important role as the main pillar of the unity of the countries in Southeast Asia. However the relationship is never smooth. From interpretation of the ups and downs that has been exposed - there are eight similarity and nine differences related to viewpoints. This shows that the relationship between Malaysia and Indonesia is still relatively balanced. But it is necessary to be cautious with the difference of one differences, because it can grow out of control if there is no "political will" to solve it. The balance is seen in the nationalism and national interests of both nations, but if one feels higher than the other it may spark a conflict.

The unstability of the IndonesiaMalaysia relations was also influenced by domestic factors. Therefore the failure or success of diplomacy processes was also largely determined by the involvement of other leaders, other than formal diplomats. What remains an obstacle to the Indonesian people until today is the Malaysian national interest that is not clear whether it is purely
Malaysian interests or whether there is Western interest behind it.

Faced with various problems, both societies interpret some alternative peace solutions through economic, political and cultural approach. But the cultural approach gets the greatest emphasis, considering that the two nations already posses strong kinship characters, also the supple and flexible nature of its culture that could enter into all sectors.

\section{REFERENCE}

Bassja, Ibrahim, Konfrontasi Republik Indonesia terhadap Malaysia : ditinjau dari sudut kepentingan nasionalnya, (Jakarta, 1968): p 117 - 118.

Donelly, Jack "The Ethics of Realism", in Christian Reus-Smit, Duncan Snidal (eds.), The Oxford Handbook of International Relations, Oxford University Press, 2008,

Djelantik, Sukawarsini, Asia pasifik, Konflik, Kerjasama, dan Relasi Antarkawasan, (Yayasan Pustaka Obor Indonesia, edisi pertama, Mei 2015)

Djiwandono, J. Soedjati, Konfrontasi Revisited : Indonesia's Foreingn Policy Under Soekarno, (1996 Center for Strategic and International Studies (CSIS), Jakarta

Dunne, T. (2001). Liberalism. In J. Baylis, \& S. Smith, The Globalization of World Politics (pp. 162-181). Oxford.

Elly M. Setiadi dan Usman Kolip, Pengantar Sosiologi, Pemahaman Fakta dan Gejala Permasalahan Sosial : Teori, Aplikasi dan Pemecahannya, (2011,Kencana, Jakarta) p : 347

Gross, Jonathan., 2001, Byron: the erotic liberal, Lanham: Rowman and Littlefield Publishers, Inc 
Hadiningrat, Kusumah. Sejarah Operasi Gabungan Dalam Rangka Dwikora, (Jakarta, Departemen PertahananKeamanan Pusat Sejarah ABRI, (1971)

Jemadu, Aleksius, Politik Global dalam Teori \& Praktik, ( Graha Ilmu, Yogyakarta, 2008) : p 152

, Negara Dalam Studi politik Global : Perdebatan Epistemologis, dalam Refleksi Teori Hubungan Internasional dari Tradisi ke Komtemporer,(2009, Graha ilmu, Yogyakarta

Jackson, Robert dan Georg Sorensen. 2009. Pengantar Studi Hubungan Internasional. Yogyakarta: Pustaka Pelajar

Morgenthau, H.J.,Politics Among Nations " the Strunggle for Power and Peace" (New York: Alferd,A Knopf,Inc,1948)

dalam T.May Rudy, Study Strategis dalam transformasi sistem Internasional Pasca Perang dingin, (Refika Aditama, Bandung, 2002)

Paloma, Margaret M Sosiologi kontemporer, (1994, Raja Grafindo Persada, Jakarta)

Pour, Julius., Benny Tragedi Seorang Loyalis, (Jakarta, Hasta Pustaka,2002).

Ritzer \& Douglas J Goodman. Teori Sosiologi Modern, Editor Triwibowo Budi Santoso, (Jakarta Prenada Media,2005),

Sarimaya, Farida et al, Dua Bangsa Melihat Masa Lalunya : Peristiwa Konfrontasi Indonesia-Malaysia (1963-1966) Sebagaimana Dikisahkan DalamBukubuku Teks Sejarahnya di Sekolah (2009, Universitas Pendidikan Indonesia)

Sugiyono, 2009. Metodologi Penelitian Kuantitatif, Kualitatif dan R\&D untuk Bidang Pendidikan (Bandung: Alvabeta)
Sunarti, Linda, Politik Luar Negeri Indonesia, 1957 - 1976, Dari Konfrontasi Menuju Kerjasama, (2014)

Susetiawan, Konflik Sosial : Kajian sosiologis hubungan buruh perusahaan dan negara di Indonesia, (2000, Pustaka Pelajar, Yogyakarta)

Syed Othman Syed Omar, Tentara Malaysia Dalam Era Konfrontasi, (Bangi, Penerbit Universiti Kebangsaan Malaysia,1969

Veegers,K.J. Realitas Sosial; Refleksi Filsafat Sosial atas Hubungan IndividuMasyarakat dalam Cakrawala sejarah Sosiologi (1993, Gramedia Pustaka Utama, Jakarta) : p 210 